\title{
Should we be giving enhanced vitamin D intakes to all?
}

\author{
${ }^{1} \mathrm{BJ}$ Boucher, ${ }^{2} \mathrm{MD}$ Witham \\ ${ }^{1}$ Honorary Professor of Medicine, Centre for Diabetes, Barts \& The London School of Medicine \& Dentistry, London, UK; ${ }^{2}$ Clinical Senior \\ Lecturer and Clinician Scientist in Ageing and Health, University of Dundee, Ninewells Hospital, Dundee, UK
}

\begin{abstract}
It is widely established that vitamin $D$ is critical for bone health. There is also an increasing body of evidence from observational studies that low levels of vitamin $D$ are associated with a range of other disorders, including cancer and cardiovascular disease. People in temperate climates are often deficient in vitamin D, particularly in wintertime. The key question is whether there is sufficient evidence to justify supplementing vitamin D intakes for all. In this 'Controversy in Medicine', two international experts argue the case 'for' and 'against' universal vitamin D supplementation.
\end{abstract}

KEYWORDS Vitamin D, 25-hydroxyvitamin D, food supplementation, osteoporosis

DECLARATION OF INTERESTS MD Witham has received grant funding from the Chief Scientist Office, Scottish Government, Diabetes UK, Heart Research UK, Chest Heart and Stroke Scotland, ME Research UK and Tenovus Scotland, to support research into vitamin D.
Correspondence to BJ Boucher, Centre for Diabetes, Barts \& The London School of Medicine \& Dentistry, Blizard Institute, 2 Newark Street, London EI 2AT, UK

e-mail bboucher@doctors.org.uk

Correspondence to MD Witham, University of Dundee

Ninewells Hospital,

Dundee DDI 9SY, UK

tel. $+44(0) / 382632436$

e-mail m.witham@dundee.ac.uk

\section{Enhanced vitamin D intakes for all? Why we should say 'yes'}

BJ Boucher

Those who do not learn from history are doomed to repeat it.'

Rickets, one of several 'English diseases', appeared during the Industrial Revolution when people moved into towns, summer sunshine was blocked by air pollution and many people worked indoors rather than outdoors, often from early childhood. ${ }^{2}$ Rickets was virtually abolished in the UK in World War II when cod liver oil supplements were offered to all pregnant and nursing mothers and children under five years of age ${ }^{3}$, and when parents 'aired' their babies outdoors. It took almost a century for the old wives tale (that cod liver oil cured rickets) to be confirmed, and the two forms of vitamin $\mathrm{D}$ (cholecalciferol and ergocalciferol), to be discovered. ${ }^{4}$ So how is it that increasing numbers of people have developed vitamin $D$ deficiency-related rickets and osteomalacia, osteoporosis has worsened and falls and fragility fractures have become more common over recent decades? This is mainly because most of us spend less time outdoors as we work, play, socialise, travel and exercise indoors, behind glass windows that block transmission of ultraviolet light (UVB). At the same time, we are advised to avoid midday sunshine in order to reduce skin cancer risks (and skin ageing) by seeking shade, covering up and using powerful sunscreens, especially for children. For the growing proportion of the UK population who are black or Asian, increased skin pigmentation reduces skin synthesis of vitamin $D$ by UVB, and, the further north we live, the less available UVB there is. Thus, instead of making enough vitamin $D$ ourselves, under tightly regulated feedback systems avoiding toxicity in normal people ${ }^{5}$, we are dependent on dietary or supplemental vitamin $D$, as a 'vitamin', to avoid overt manifestations of vitamin D deficiency both in the UK and globally as the problem of deficiency becomes increasingly common in both sunny and temperate climates. ${ }^{6}$

Those reading this debate in Scotland are even more likely to be vitamin $D$ insufficient than readers in southern parts of the UK.' The problem gets worse with age as skin synthesis and gut absorption of vitamin $D$ become less efficient. ${ }^{89}$ This situation is also exacerbated in those with reduced mobility, loss of independence, and especially in those in residential care. ${ }^{10}$ There is a large body of evidence associating hypovitaminosis $D$ with increased risks for many diseases, in virtually all systems of the body and not just in the musculoskeletal system. Serum 25-hydroxyvitamin $\mathrm{D}(25[\mathrm{OH}] \mathrm{D})$ is generally accepted as a measure of vitamin $D$ repletion (status). The significance of this measurement in the investigation of disease relates to the fact that $25(\mathrm{OH}) \mathrm{D}$ is activated locally in target tissues, free of feed-back regulation. This local activation is directly dependent on serum $25(\mathrm{OH}) \mathrm{D}$ concentration, explaining the physiological significance of serum $25(\mathrm{OH})$ D concentration for human health. ${ }^{11-13}$ 
These data cover associations and mechanisms for cardiovascular disease, innate and acquired immunity, infections, autoimmune disease (especially multiple sclerosis), inflammatory disorders and psoriasis. Higher vitamin $\mathrm{D}$ status is associated with reduced risks, crosssectionally and often prospectively, for these disorders, including melanoma, the most aggressive skin cancer and itself triggered by sunburn. ${ }^{14-21}$ However, randomised controlled trial (RCT) data indicating adequate supplementation with vitamin $\mathrm{D}$ for non-bony conditions is still insufficient to prove causality. For bone mineral density, muscle strength, falls and fragility fractures, intakes of at least $800 \mathrm{IU} /$ day of vitamin $\mathrm{D}$ reduces risk, though massive doses may increase these risks temporarily. ${ }^{22-26}$ Thus, our evidence base supports the need to return to the situation achieved during World War II, when the reduction in vitamin D deficiency lowered the risks of rickets and osteomalacia; it does not however support the use of supplemental intakes (above 800 to $1000 \mathrm{IU} /$ day) in the long-term in healthy people for reducing non-bony health risks. Indeed, history teaches us that other potential 'magic bullets' thought to reduce several major health risks can prove ineffective and may even increase those risks (e.g. RCTs using beta-carotene with vitamin $A$ for prevention of lung cancer and heart disease). ${ }^{27}$ The problems with the use of beta-carotene probably resulted from confounding by other dietary factors; similar confounding by unidentified factors affecting vitamin $D$ status cannot as yet be excluded.

These considerations contributed to the recent Institute of Medicine (IOM) recommendations from the US that dietary intakes in the population as a whole should reach $400 \mathrm{lU} /$ day in infants and children, $600 \mathrm{lU} /$ day in adults and pregnant and nursing mothers, and $800 \mathrm{IU} /$ day in older people (and by implication, others at increased risk of $\mathrm{D}$ deficiency, e.g. dark skinned, vegetarians and vegans ${ }^{28}$ ). Vitamin $D$ deficiency is increasingly common worldwide and is known to increase infant mortality (from acute heart failure or hypocalcaemic fits), ${ }^{3}$ and is also associated with increased adult mortality. ${ }^{29}$ Disagreement on defining 'deficiency' based on serum $25(\mathrm{OH}) \mathrm{D}$ assays is common. Genetic variation in the vitamin $D$ axis has a small independent effect on serum $25(\mathrm{OH}) \mathrm{D}$ concentration, but the literature demonstrates a reasonable consensus that values of $<50 \mathrm{nmol} / \mathrm{l}$ by any assay reflect a deficiency severe enough to lead to clinically obvious bone problems. ${ }^{30,12}$ Thus, in countries where this value is not reached by the majority of residents across all seasons of the year, the population should benefit, in bone health at least, from increasing vitamin $D$ intakes to achieve $25(\mathrm{OH}) \mathrm{D}$ values of at least $50 \mathrm{nmol} / \mathrm{l}$. In the young, 25(OH)D concentrations above $50 \mathrm{nmol} / \mathrm{l}$ increase bone density 'dose-wise', reducing bone risks in later life. ${ }^{32}$ Thus, $50 \mathrm{nmol} / \mathrm{l}$ is a serum $25(\mathrm{OH}) \mathrm{D}$ target level likely to be raised as new evidence accrues. In Scotland, a recent report on post-menopausal women showed that they never reach a mean $25(\mathrm{OH}) \mathrm{D}$ concentration of $50 \mathrm{nmol} / \mathrm{l}$ at any season of the year. ${ }^{33} \mathrm{In}$ winter, $40 \%$ of post-menopausal women in Surrey were deficient (10\% of Caucasian and $65 \%$ of Asian women). In summer, $16 \%$ were deficient $(0 \%$ of White and $>50 \%$ of Asian women). Higher values, e.g. $75-110 \mathrm{nmol} / \mathrm{l}$, are associated with health benefits in observational studies. At higher, but non-toxic, concentrations, however, there are suggestions of possible adverse effects that need further investigation. ${ }^{34,35}$ Better maternal vitamin D status improves bone health in children aged 9 years old, ${ }^{36}$ and other possible transgenerational effects require study.

Vitamin D deficiency $(25(\mathrm{OH}) \mathrm{D}<25 \mathrm{nmol} / \mathrm{l})$ is found at all ages in the UK in $5-15 \%$ of Caucasian people. It rises to $>20 \%$ in those aged between 19-24 years, increasing again after the age 60 and reaching $>40 \%$ in people in their 80 s. A lesser degree of deficiency $(25(\mathrm{OH}) \mathrm{D}$ $<50 \mathrm{nmol} / \mathrm{l}$ ) is never found in less than $20 \%$ of the Caucasian population at any age and is found in $>40 \%$ of people over the age of II years old; in $>60 \%$ of those aged between 19-24 years, and increases in over 65-yearolds, peaking at $>80 \%$ among those living in an institutional setting. ${ }^{37}$ This nationwide problem requires urgent attention. Preventative public health measures would be more cost-effective than medical management: provision of 400-800 IU/day using Healthy Start supplements costs less than $£ 4 /$ year ( 2010 prices) but one $25(\mathrm{OH}) \mathrm{D}$ assay costs $£ 10.50-£ 25 .{ }^{3}$ The costs of modest food fortification would, as for other foods, be passed on to consumers. In Finland, voluntary food fortification with vitamin $D$ has reduced the prevalence of vitamin $D$ deficiency $(25(\mathrm{OH})$ $\mathrm{D}<50 \mathrm{nmol} / \mathrm{l})$ significantly in most population groups. ${ }^{38,39}$ This approach, already widely used in the USA and enforced by statute in the UK since 1942 (but only for margarine [at 280-350 IU/I00G ${ }^{40}$ ]), requires care to avoid excessive intakes in infants. ${ }^{3}$ Ultraviolet $B$ (UVB) irradiation of certain vegetables, notably mushrooms and yeast, increases vitamin D content and is used in some countries, ${ }^{3}$ and may prove more useful than trying to ensure controlled UVB irradiation of the skin. Surveys of representative population groups and checks on food content would be needed to audit the adequacy of provision and its safety at the population level. Such audits and safety checks would be expected to lead to adjustment of fortification levels where necessary.

The many studies of vitamin D status in the UK over recent years have clearly not been acted upon, and this must change. ${ }^{41}$ Even modest risk reductions in musculoskeletal vitamin D deficiency disorders, acute neonatal heart failure, rickets, the severity and costs of osteoporosis and its painful complications, and in fragility fractures (in the 25,000 overt vertebral fractures and the 70,000 annual hip fractures in England and Wales which have a falling in-patient mortality but a continuing 
mortality of $20 \%$ after six months and $30 \%$ by one year, with a $50 \%$ loss of independence ${ }^{42-45}$ ) would, clearly, be welcome to sufferers and their families and would also reduce NHS costs. At present, the NHS has no recommendations for vitamin $D$ intake levels for those aged between 19 and 64 years old. ${ }^{3.37}$ Compliance with oral supplementation is well known to be poor (reducing to $50 \%$ after six months in those being treated for osteoporosis). In the UK supplements on prescription usually contain either calcium (which can cause constipation, reducing compliance and, in supplements, may increase cardiovascular risks ${ }^{4}$ ) or vitamin $A$ which antagonises vitamin D.,48 It would be helpful, therefore, if the British National Formulary (BNF) included preparations of vitamin $D$ alone, at a range of doses, to facilitate treatment of people presenting clinically with deficiency related disorders. While many pregnant and

\section{REFERENCES}

I Winston Churchill, based on George Santayana 'Those who cannot remember the past are condemned to repeat it.' In: Santayana G. Reason in common sense. 1905.

2 Gibbs DD. Rickets and the crippled child: an historical perspective. J R Soc Med 1994; 87:729-32.

3 Hyppönen E, Boucher BJ.Avoidance of vitamin D in pregnancy in the United Kingdom: the case for a unified approach in national policy. $\mathrm{Br}$ Nutr 2010; 104:309-14. http://dx.doi.org/I0.1017/S0007/ I4510002436

4 Hirsch AL. Industrial aspects of vitamin D. In: Feldman D, Pike JW Adams JS, editors. Vitamin D. International: Academic Press; 2011. p. 73-93. http://dx.doi.org//0.1016/B978-0-12-381978-9.10006-X

5 Holick MF. Vitamin D: evolutionary, physiological and health perspectives. Curr Drug Targets 201I; 12:4-18. http://dx.doi. org/I0.2I74/I389450II79359I635

6 Prentice A.Vitamin D deficiency: a global perspective. Nutr Rev 2008 66:SI53-64. http://dx.doi.org/I0.1 III/j. 1753-4887.2008.00100.x

7 Hyppönen E, Power C. Hypovitaminosis D in British adults at age $45 \mathrm{y}$ : nationwide cohort study of dietary and lifestyle predictors. Am J Clin Nutr 2007; 85:860-68.

8 Lund B, Sorensen $\mathrm{OH}$. Measurement of 25-hydroxyvitamin D in serum and its relationship to sunshine, age and vitamin $D$ intake in the Danish population. Scand J Lab Invest 1979; 39:23-30. http:// dx.doi.org// 0.3109/003655/7909/04935

9 Barragry JM, France MW, Corless D et al. Intestinal cholecalciferol absorption in the elderly and younger adults. Clin Sci Mol Med 1978; 55:213-20.

10 Corless D, Gupta SP, Switala S et al. Response of plasma-25hydroxyvitamin $\mathrm{D}$ to ultraviolet irradiation in long-stay geriatric patients. Lancet 1978; 2:649-5I. http://dx.doi.org//0.1016/S0I406736(78)92760-5

II Adams JS, Hewison M. Update in vitamin D. J Clin Endocrinol Metab 2010; 95:47/-78. http://dx.doi.org//0.12/0/jc.2009-1773

12 Holick MF. Vitamin D deficiency. N Engl J Med 2007; 357:266-81. http://dx.doi.org/I0.1056/NEJMra070553

13 Feldman D, Pike JW, Adams JS, editors. Vitamin D. International: Academic Press; 20II.

14 Grant WB, Boucher BJ. Requirements for vitamin D across the lifespan. BiolResNurs 201 I; 13: I 20-33.http://dx.doi.org//0.I I77/10998004/039|243

15 Handunnetthi L, Ramagopalan SV, Ebers GC. Multiple sclerosis, vitamin D and HLA-DRBI*I5. Neurology 2010; 74:1905-10. http:// dx.doi.org/I0.12/2/WNL.0b013e3/8I e24/24

16 Forouhi NG,Luan J,CooperA et al. Baseline serum 25-hydroxyvitamin $D$ is predictive of future glycemic status and insulin resistance: The Medical Research Council Ely Prospective Study 1990-2000. Diabetes 2008; 57:2619-25. http://dx.doi.org//0.2337/db08-0593 nursing women might take supplements, as they do folic acid, others might not use them regularly, even if they could afford them, or even if they were free of charge for all.

Thus, food fortification, adjusted to achieve serum $25(\mathrm{OH}) \mathrm{D}$ concentrations across the healthy adult population of at least $50 \mathrm{nmol} / \mathrm{l}$ (but ideally $<150 \mathrm{nmol} / \mathrm{l}$ ) would provide a safe, acceptable and cost-effective way of reducing health risks from musculoskeletal disorders known to benefit from improved vitamin $D$ intakes, with reduced fracture risks confirmed in corrected metaanalysis of data for 68,500 patients in seven trials. ${ }^{49}$ This could be introduced while we await the outcomes of large scale RCTs currently in progress on the efficacy and safety of higher doses, ${ }^{50-51}$ before we can judge what is 'not too little and not too much but just right'.52

17 Mitri J, Muraru MD, Pittas AG et al.Vitamin D and type 2 diabetes: a systematic review. Eur J Clin Nutr 201 I; 65:1605-15. http://dx.doi. org/I0.1038/ejcn.20II.II8

18 Boucher BJ. Vitamin D insufficiency and diabetes risks. Curr Drug Targets 20 I I; 12:6 I-87.http://dx.doi.org//0.2 I74//389450 I I79359/653

19 Grandi NC, Breitling LP, Brenner H. Vitamin D and cardiovascular disease: systematic review and meta-analysis of prospective studies. Prev Med 2010; 51:228-33. http://dx.doi.org/10.1016/j.ypmed.2010.06.013

20 Newton-Bishop JA, Chang YM, Eliott F et al. Relationship between sun exposure and melanoma risk for tumours in different body sites in a large case-control study in a temperate climate. Eur J Cancer 20I I; 47:732-4I. http://dx.doi.org/I0.10I6/j.ejca.2010.10.008

21 Field S, Newton-Bishop JA. Melanoma and vitamin D. Mol Oncol 20I I; 5:197-214. http://dx.doi.org/I0.1016/j.molonc.20II.0I.007

22 Karalus J, Chlebna-Sokól D. The clinical efficacy of vitamin D in children with primary low bone mass. Pediat Endocrinol Diabetes Metab 20II; 17:35-40.

23 Bischoff-Ferrari HA, Willett WC,Wong JB et al. Prevention of nonvertebral fractures with oral vitamin $D$ and dose dependency: a meta-analysis of randomized controlled trials. Arch Int Med 2009; 169:55I-6I. http://dx.doi.org//0.100 I/archinternmed.2008.600

24 Bischoff-Ferrari HA, Dawson-Hughes B, Staehelin HB et al. Fall prevention with supplemental and active forms of vitamin $D$ : a meta-analysis of randomized controlled trials. BMJ 2009; 339:b3692. http://dx.doi.org// 0.1 I36/bmj.b3692

25 Zhu K, Devine A, Dick IM et al. Effects of calcium and vitamin D supplementation on hip bone mineral density and calcium-related analytes in elderly ambulatory Australian women: a five year randomized controlled trial. J Clin Endocrinol Metab 2008; 93:74349. http://dx.doi.org/10.1210/jc.2007-1466

26 Sanders KM, Stuart AL, Williamson EJ et al. Annual high-dose oral vitamin $D$ and falls and fractures in older women: a randomized controlled trial.JAMA 2010; 303:1815-22. http://dx.doi.org//0.100I/ jama.2010.594

27 Fritz H, Kennedy D, Fergusson D et al. Vitamin A and retinoid derivatives for lung cancer: a systematic review and metaanalysis. PloS One 20I I; 6:e21 107. http://dx.doi.org/10.1371/journal. pone.002II07

28 Ross AC, Manson JE, Abrams SA et al. The 201 I report on dietary reference intakes for calcium and vitamin $D$ from the Institute of Medicine: what clinicians need to know. J Clin Endocrinol Metab 201 I; 96:53-58. http://dx.doi.org/10.1210/jc.2010-2704

29 Bjelakovic G, Gluud LL, Nikolova D et al. Vitamin D supplementation for prevention of mortality in adults. Cochrane Database Syst Rev 201 I; 7:CD007470. 
30 Berry DM Hypponen E. Determinants of vitamin D status: focus on genetic variations. Curr Opin Nephrol Hypertens 20I I; 20:33I36. http://dx.doi.org//0.1097/MNH.0b0 I3e328346d6ba

3I Malabanan A, Veronikis IE, Holick MF. Redefining vitamin D insufficiency. Lancet 1998; 351:805-6. http://dx.doi.org/10.1016/ SOI40-6736(05)78933-9

32 Bischoff-Ferrari HA, Dietrich T, Orav EJ et al. Positive association between 25-hydroxyvitamin $D$ levels and bone mineral density: a population-based study of younger and older adults. Am J Med 2004; I I 6:634-39. http://dx.doi.org/ I0.10 I6/j.amjmed.2003.12.029

33 Macdonald HM, Mavroeidi A, FraserWD et al. Sunlight and dietary contributions to the seasonal vitamin D status of cohorts of healthy postmenopausal women living in northerly latitudes: a major cause for concern? Osteoporos Int 201 I; 22:246I-72. http:// dx.doi.org/I0.1007/s00198-010-1467-z

34 Bodnar LM, Catov JM, Zmuda JM et al. Maternal serum 25-hydroxyvitamin D concentrations are associated with smallfor-gestational age births in white women. J Nutr 2010; 140:9991006. http://dx.doi.org/10.3945/jn.109.119636

35 Michaëlsson K, Baron JA, Sneliman G et al. Plasma vitamin D and mortality in older men: a community-based prospective cohort study. Am J Clin Nutr 2010; 92:84I-48. http://dx.doi.org/I0.3945/ ajcn.2010.29749

36 Javaid MK, Crozier SR, Harvey NC et al. Maternal vitamin D status during pregnancy and childhood bone mass at age 9 years: a longitudinal study.Lancet 2006;367:36-43. http://dx.doi.org//0.1016/ S0I40-6736(06)67922-I

37 Henderson LB, Prentice A, Perks J et al. The National Diet and Nutrition Survey: Adults aged 19-64 years - vitamin and mineral intake and urinary analytes [Internet]. London: The Stationery Office; 2003 [cited 20I I Nov 8]. Available from: http://www.food.gov.uk/multimedia/pdfs/ ndnsv3.pdt

38 O'Donnell S, Cranney A, Horsley T et al. Efficacy of food fortification on serum 25-hydroxyvitamin D concentrations: a systematic review. Am J Clin Nutr 2008; 88:1528-34. http://dx.doi. org/I0.3945/ajen.2008.264I5

39 Lanham-New S, Buttriss JL, Miles LM et al. Proceedings of the Rank Forum on Vitamin D. Br J Nutr 20I I; I05: I44-56. http://dx.doi. org/I0.1017/S0007II4510002576

40 HM Government. The Spreadable Fats (Marketing Standards) Regulations 1995. London: The National Archives; 1995.

41 Gillie O. Sunlight robbery: a critique of public health policy on vitamin D in the UK. Mol Nutr Food Res 2010; 54: I I48-63.
$42 \mathrm{Wu}$ TY, Jen MH, Bottle A et al. Admission rates and in-patient hospital mortality for hip fractures in England 1998-2009: time trends study. J Public Health (Oxf) 20I I; 33:284-91. http://dx.doi. org/10.1093/pubmed/fdq074

43 Scottish Intercollegiate Guidelines Network. Management of osteoporosis. A national clinical guideline (June 2003) [Internet]. Edinburgh: SIGN; 2003 [cited 20I I Nov 8]. Available from: http:// www.sign.ac.uk/pdf/sign7l.pdf

44 Trivedi DP, Doll R, Khaw KT. Effect of four monthly oral vitamin D3 (cholecalciferol) supplementation on fractures and mortality in men and women living in the community: randomised double blind controlled trial. BMJ 2003; 326:469. http://dx.doi.org/ I0. I I36/ bmj.326.7387.469

45 National Institute for Health and Clinical Excellence. Osteoporosis - secondary prevention including strontium ranelate: Final appraisal determination (July 2008) [Internet]. London: NICE; 2008 [cited 20 I I Nov 8]. Available from: http://www.nice.org.uk/nicemedia/ pdf/OsteoporosisSecondaryPreventionFADJul08.pdf

46 Sanders KM, Stuart AL, Merrimen EN et al. Trials and tribulations of recruiting 2,000 older women onto a clinical trail investigating falls and fractures: Vital D study. BMC Med Res Methodol 2009; 9:78. http://dx.doi.org/10.1/86/147/-2288-9-78

47 Boucher BJ. Calcium supplements may increase the risk of cardiovascular events in postmenopausal women [commentary]. Evid Based Med 201 I; Epub 20 I I Oct 25. http://dx.doi.org/ I0.I I 36/ ebm.2011.100113

48 Johansson S, Melhus $\mathrm{H}$. Vitamin A antagonises calcium response to vitamin D in man. J Bone Miner Res 200I; 16:1899-1905. http:// dx.doi.org/10.1359/jbmr.2001.16.10.1899

49 DIPART (Vitamin D Individual Patient Analysis of Randomized Trials) Group. Patient level pooled analysis of 68,000 patients from seven major vitamin D fracture trials in US and Europe. BMJ 20 I I;343:d5246. http://dx.doi.org//0.1 I36/bmj.d5245. Corrected and republished from: BMJ 20I0; 340:b5463. http://dx.doi.org/I0.I I36/bmj.b5463

50 Current controlled trials.com [Internet]. Biomed Central. [cited 201 I Nov 8]. metaRegister of controlled trials - active registers. Available from: http://www.controlledtrials.com/mrct/search.html

5I Hollis BW, Johnson D, Hulsey TC et al.Vitamin D supplementation during pregnancy: double blind randomized clinical trial of safety and effectiveness.J Bone Miner Res 20I I; 26:234I-57. http://dx.doi. org/10.1002/jbmr.463

52 The Goldilocks principle, based on The Story of the Three Bears, an update of an old folk tale by Robert Southey.

\section{Enhanced vitamin D intakes for all? Why we should say 'no'}

MD Witham

It would be easy to assume, given the excited media coverage that vitamin $D$ generates, that the case for universal supplementation was already proven. Vocal lobbying is however no substitute for scientific evidence, and for vitamin $D$, we do not have the understanding of its biological effects or the required evidence for the efficacy or safety of universal supplementation.

There are several major disease targets that vitamin D supplementation might potentially ameliorate - bone health, cancer, cardiovascular disease, autoimmune disease (including multiple sclerosis and type I diabetes) and metabolic disease including type 2 diabetes. What evidence do we have that supplementation at the population level would improve outcomes in these conditions?
Evidence for bone health is probably the strongest. Observational studies suggest that supplementation with low doses of vitamin D reduces the risk of rickets,' and in selected older people (particularly those in institutional care), calcium and vitamin $D$ supplements reduce the risk of falls and osteoporotic fracture. ${ }^{2}$ However, these benefits do not appear to extend to community-dwelling older people, even if they have had a previous fracture ${ }^{3}$, and the Women's Health Initiative (WHI) trial ${ }^{4}$ did not show a significant reduction in hip fracture when supplementing a large, population-based cohort with low-dose vitamin D and calcium.

Although prospective observational data links low 25 -hydroxyvitamin D (25[OH]D) levels with an increased risk of cardiovascular events, supplementation trials 
devised to specifically reduce the risk of cardiovascular events have not been performed. Meta-analysis of existing osteoporosis trials (which are clearly not representative of the general population) show no reduction in myocardial infarction or stroke, ${ }^{5}$ and the effect of supplementation on cardiovascular risk factors has been variable; some but not all studies show improvement in endothelial function (a powerful marker of cardiovascular risk), ${ }^{6-8}$ but there appears to be little effect on lipid levels, and blood pressure is modestly reduced only in those with elevated blood pressure at baseline. ${ }^{9}$

Data on cancer outcomes in supplementation trials is even scantier. The WHI trial showed no reduction in colorectal cancer, ${ }^{10}$ and the one trial frequently quoted to show an effect of vitamin D on cancer rates (again as a secondary analysis of an osteoporosis trial) actually showed a reduction in new cancers with calcium supplements, but no additional reduction when vitamin D was combined with calcium." Observational data are not easy to interpret; although there appears to be a lower cancer incidence with increasing 25(OH)D levels in most studies, a few studies show the opposite, albeit with better cancer survival with higher vitamin $D$ levels.

Both type I and type 2 diabetes mellitus have been linked with lower $25(\mathrm{OH}) \mathrm{D}$ levels, but evidence that vitamin $D$ supplementation can prevent the occurrence of type I diabetes is lacking, and the available evidence from randomised controlled trials does not suggest any effect on rates of type 2 diabetes to date. ${ }^{2}$ Even in patients with pre-existing diabetes or impaired fasting glucose, vitamin D supplements appear to produce only a small improvement in insulin resistance and fasting glucose - and no improvement in long-term glycaemic control. Once again, robust data from large, long-term trials are lacking.

The evidence base for other health conditions, for example multiple sclerosis, is even flimsier, with no intervention studies to guide practice. Several trials across a variety of populations at risk from a number of infections have now been performed to assess whether vitamin $D$ supplementation can reduce infection rates, especially rates of respiratory tract infection and tuberculosis; results have been mixed at best, as confirmed by a recent systematic review. ${ }^{13}$

No large randomised controlled trials have been conducted to examine the effect of vitamin D supplementation on overall mortality in a general population; meta-analysis of existing trials (mostly for osteoporosis and fracture prevention) suggest either a small effect on mortality (absolute risk reduction of $0.5 \%)^{14}$ or no effect. ${ }^{5}$ It cannot be assumed that any benefit in a group at such high risk of death as those with osteoporosis will apply to a general population.
What about potential harms? These are of particular importance in any population-level intervention, as large numbers of healthy people (i.e. with little scope for accruing benefits) will receive exposure to the potential harm. It is unlikely that universal supplementation will cause overt toxicity; the doses required for this appear to be very large indeed. ${ }^{15}$ However, the WHI trial ${ }^{4}$ showed a $16 \%$ higher risk of renal and ureteric stones in the treatment group (who received only $400 \mathrm{U}$ of vitamin D3). Observational data point to higher immunoglobulin E (lgE) levels in people with 25(OH)D levels above $135 \mathrm{nmol} / /{ }^{16}$ higher rates of atopic disorders in the offspring of women with 25(OH)D levels $>75 \mathrm{nmol} / \mathrm{l}$ during pregnancy ${ }^{17}$ and two observational studies suggest a slightly higher risk of cardiovascular events in those with the highest 25(OH)D levels, ${ }^{18.19}$ compared with people with moderate $25(\mathrm{OH}) \mathrm{D}$ levels. Finally, there is the concern that patients with primary hyperparathyroidism (often undiagnosed until a routine serum calcium level is checked) could suffer from elevated, and therefore potentially symptomatic, hypercalcaemia. Are these potential risks borne out in practice? Do they outweigh potential benefits at a population level? The truth is, we simply don't know, and until we conduct the appropriate large-scale intervention trials, we will not know.

In conclusion, the benefits of universal supplementation are unproved, the risks are unknown, and we require further evidence before committing to such a public health intervention. Observational and in vitro studies are a poor guide here; let us not forget how vitamins C, $E$ and beta-carotene moved from early promise to useless (and indeed potentially harmful) interventions; ${ }^{20}$ witness the failure of $B$ group vitamins to improve vascular outcomes, and compare the current controversy surrounding folate supplementation and cancer risk. What is good for one group may also not be good for all; we need to evaluate and tailor the balance of benefit and risk for each group of people that we care for. To supplement the entire population with vitamin $D$ in the absence of good data that the benefits outweigh the risks for each individual would be poor medicine and an abrogation of our duty of care to individuals. 


\section{REFERENCES}

I Wagner CL, Greer FR. Prevention of rickets and vitamin D deficiency in infants, children, and adolescents. Pediatrics 2008; I22: I |42-52. http://dx.doi.org//0.1542/peds.2008-1862

2 Avenell A, Gillespie WJ, Gillespie LD et al.Vitamin D and vitamin D analogues for preventing fractures associated with involutional and post-menopausal osteoporosis. Cochrane Database Syst Rev 2009; CD000227.

3 Grant AM, Avenell A, Campbell MK et al. Oral vitamin D3 and calcium for secondary prevention of low-trauma fractures in elderly people (Randomised Evaluation of Calcium Or vitamin D, RECORD): a randomised placebo-controlled trial. Lancet 2005; 365:I62 I-28. http://dx.doi.org//0.10 I6/S0|40-6736(05)630I3-9

4 Jackson RD, LaCroix AZ, Gass $M$ et al. Calcium plus vitamin D supplementation and the risk of fractures. N Engl J Med 2006; 354:669-83. http://dx.doi.org// 0.1056/NEJMoa0552 I8

5 Elamin MB, Abu Elnour NO, Elamin KB et al. Vitamin D and cardiovascular outcomes: a systematic review and meta-analysis. J Clin Endocrinol Metab 20I I; 96:1931-42. http://dx.doi.org/I0.1210/ ic.20II-0398

6 Tarcin O, Yavuz DG, Ozben B et al. Effect of vitamin D deficiency and replacement on endothelial function in asymptomatic subjects. J Clin Endocrinol Metab 2009;94:4023-30. http://dx.doi.org//0.1210/ jc.2008-1212

7 Sugden JA, Davies JI, Witham MD et al. Vitamin D improves endothelial function in patients with type 2 diabetes mellitus and low vitamin D levels. Diabet Med 2008; 25:320-25. http://dx.doi. org/I0.IIII/j.I464-549I.2007.02360.x

8 Witham MD, Dove FJ, Dryburgh $M$ et al. The effect of different doses of vitamin D3 on markers of vascular health in patients with type 2 diabetes: a randomised controlled trial. Diabetologia 2010; 53:2 I I 2-19. http://dx.doi.org/ I0. I007/s00 I25-0 I0-I838-I

9 Witham MD, Nadir MA, Struthers AD. Effect of vitamin D on blood pressure: a systematic review and meta-analysis. J Hypertens 2009; 27:1948-54. http://dx.doi.org/I0.1097/HJH.0b0I3e32832f075b
10 Wactawski-Wende J, Kotchen JM, Anderson GL et al. Calcium plus vitamin $\mathrm{D}$ supplementation and the risk of colorectal cancer. $N$ Engl J Med 2006; 354:684-96. http://dx.doi.org/I0.I056/NEJMoa055222

I I Lappe JM, Travers-Gustafson D, Davies KM et al. Vitamin D and calcium supplementation reduces cancer risk: results of a randomized trial. Am J Clin Nutr 2007; 85: I586-9I.

12 Pittas AG, Chung M, Trikalinos T et al. Systematic review: vitamin D and cardiometabolic outcomes. Ann Intern Med 2010; I52:307-I4.

I3 Yamshchikov AV, Desai NS, Blumberg HM et al. Vitamin D for treatment and prevention of infectious diseases: a systematic review of randomized controlled trials. Endocr Pract 2009; I 5:438 49. http://dx.doi.org//0.4I58/EP09I0I.ORR

14 Autier P, Gandini S.Vitamin D supplementation and total mortality: a meta-analysis of randomized controlled trials. Arch Intern Med 2007; I67: 1730-37.http://dx.doi.org/I0.100 I/archinte.I67.I6.I730

I5 Vieth R. Vitamin D supplementation, 25-hydroxyvitamin D concentrations, and safety. Am J Clin Nutr 1999; 69:842-56.

16 Hypponen E, Berry DJ, Wjst M et al. Serum 25-hydroxyvitamin D and $\operatorname{lgE}-$ a significant but nonlinear relationship. Allergy 2009; 64:6 I3-20. http://dx.doi.org/I0.I I I I/j.I398-9995.2008.01865.x

17 Gale CR, Robinson SM, Harvey NC et al. Maternal vitamin D status during pregnancy and child outcomes. Eur J Clin Nutr 2008; 62:68-77. http://dx.doi.org/10.1038/sj.ejcn.1602680

18 Wang TJ, Pencina MJ, Booth SL et al.Vitamin D deficiency and risk of cardiovascular disease. Circulation 2008; I 17:503-I I. http://dx.doi. org/I0.II6I/CIRCULATIONAHA.107.706/27

19 Rajasree S, Rajpal K, Kartha CC et al. Serum 25-hydroxyvitamin D3 levels are elevated in South Indian patients with ischemic heart disease. Eur J Epidemiol 200 I; I7:567-7I. http://dx.doi.org/I0.1023/A:I014559600042

20 Druesne-Pecollo N, Latino-Martel P, Norat T et al. Beta-carotene supplementation and cancer risk: A systematic review and metaanalysis of randomized controlled trials. Int J Cancer 2010; 127:17284. http://dx.doi.org//0.1002/ijc. 25008

\section{UPCOMING SYMPOSIA}

\begin{tabular}{|c|c|c|}
\hline & Moving points in medicine (Dundee) & 8 February \\
\hline 므 & Infectious Diseases (Edinburgh) & 24 February \\
\hline 모 & Respiratory/Neurology (Aberdeen) & 7 March \\
\hline 므 & Respiratory Medicine (Edinburgh) & 14 March \\
\hline 므 & Care of the Elderly (Edinburgh) & 30 March \\
\hline 무 & Genetics (Edinburgh) & 20 April \\
\hline 모 & Oncology (Edinburgh) & 10 May \\
\hline ㅁ & Rheumatology (Edinburgh) & 19 September \\
\hline - & Paediatrics (RCPE/RCPCH joint symposium) & 27 September \\
\hline & Book online at http://events.rc & \\
\hline
\end{tabular}

Live links are available to most symposia
All symposia are held at the Royal College of Physicians of Edinburgh unless otherwise stated.

Programme details at: http://events.rcpe.ac.uk or contact the Symposium Co-ordinator: Email: e.strawn@rcpe.ac.uk

Webstreamed lectures If you are unable to attend symposia at the College in Edinburgh, selected lectures from all symposia are available to view and listen to in the Online Education Portal. http://learning.rcpe.ac.uk

There are currently more than 100 lectures covering all the medical specialties and a range of generic topics. 